\title{
Gambaran Sistem Rujukan Terintegrasi (Sisrute) Di RSUD Dr. RM Djoelham Binjai Tahun 2019
}

\author{
${ }^{1}$ Lamtiur Junita Bancin, ${ }^{2}$ Nurul Arrizka Putri, ${ }^{3}$ Nurul Rahmayani, \\ ${ }^{4}$ Ransiska Kharisma, ${ }^{5}$ Silvi Widya Purba \\ Program Studi D-IV Manajemen Informasi Kesehatan, Universitas Imelda Medan
}

\begin{tabular}{l}
\hline \hline Article Info \\
\hline Article history: \\
Received Feb 12, 2020 \\
Revised Feb 15, 2020 \\
Accepted Feb 28, 2020 \\
\hline
\end{tabular}

\section{Keywords:}

Sisrute

Referral

Integrated

Application

\begin{abstract}
ABSTRAK
Integrated Referral System (Sisrute) is an application for the delivery of health services between health facilities. Sisrute referral level health services consist of secondary and tertiary health facilities. Sisrute has a function in assisting the formulation of strategic and technical policies in the field of sustainable referral health and supporting the implementation of local government in the health sector. The purpose of this study is to determine the flow of Sisrute, the constraints and advantages of the application of the Sisrutedi Hospital Dr.RM Djoelham Binjai. This type of research is descriptive research. The data source used is secondary data that is already in the hospital. In this study the data analysis was done descriptively through observation, presentation and conclusion drawing, so an overview of Sisrute was obtained. Sisrute application is very helpful in accelerating service, facilitating referral information related to patient clarity can be received by the referral hospital, easy to conduct consultations in handling patients more directed and minimizing patient refusal by coordination and communication between RSUD Dr. RM Djoelham Binjai with the hospital that you want to refer to / RS recipient. The constraints of using Sisrute are: The Internet server is unstable and the patient data referenced is incomplete in accordance with the form in the system making it difficult for the recipient hospital to receive answers. The advantage of using Sisrute is that the referrer can find out the purpose of the Hospital according to the needs of the patient, ensuring the patient has received treatment from the referred hospital, the referrer can be certain of the patient to be referred.
\end{abstract}

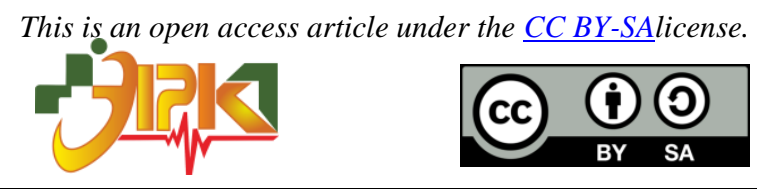

\section{Corresponding Author:}

Lamtiur Junita Bancin,

Program Studi D-IV Manajemen Informasi Kesehatan,

Universitas Imelda Medan,

Jl. Bilal No. 52 Kelurahan Pulo Brayan Darat I Kecamatan Medan Timur, Medan - Sumatera Utara.

Email: lamtiurjunitabancin@yahoo.com

\section{PENDAHULUAN}

Rumah sakit sebagai institusi pelayanan kesehatan memiliki peranan penting dalam penyelenggaraan pelayanan kesehatan perorangan secara paripurna. Pelayanan kesehatan yang tersedia dapat berupa pelayanan rawat inap, rawat jalan, dan gawat darurat (UU No 44 Tahun 2009). Selain itu, jenis pelayanan rumah sakit terdiri dari pelayanan medis, pelayanan rehabilitasi, pencegahan atau prevensi dan peningkatan kesehatan sebagai tempat pendidikan 
serta dapat menjadi wadah penelitian dan pengembangan ilmu dan teknologi bidang kesehatan (Permenkes, 2004).

Rumah sakit memiliki kewajiban dalam hal pencatatan dan pelaporan terhadap kegiatan penyelenggaraan rumah sakit tersebut. Pencatatan dan pelaporan tersebut disajikan dalam bentuk sistem informasi manajemen rumah sakit atau dikenal dengan SIMRS (Permenkes, 2011).

Sistem informasi rumah sakit merupakan tatanan berkaitan dengan pengumpulan data (data collection), pengelolaan data (data management or analysis), penyajian informasi, pelaporan analisis dan penarikan informasi menjadi kesimpulan yang secara komprehensif dibutuhkan untuk kegiatan rumah sakit (Permenkes, 2011).

Penyelenggaraan pelayanan kesehatan membutuhkan Pemanfaatan teknologi informasi dan komunikasi (TIK) guna meningkatkan akses dan mutu layanan kesehatan. Sistem Rujukan Terintegrasi (Sisrute) merupakan sebuah aplikasi untuk penyelenggaraan pelayanan kesehatan antar Fasilitas kesehatan. Sisrute Pelayanan kesehatan tingkat rujukan terdiri atas fasilitas kesehatan sekunder dan tersier.

Pelayanan tingkat sekunder yaitu pelayanan kesehatan yang setara rumah sakit tipe C dan D. Pelayanan tingkat tersier yaitu pelayanan kesehatan rumah sakit tipe A dan tipe B, pelayanan kesehatan tingkat rujukan menerima rujukan dari tingkat pelayanan kesehatan dibawahnya. Sisrute sebagai aplikasi terbaru dalam penyelenggaraan pelayanan kesehatan secara elektronik untuk sistem rujukan mengatur pelimpahan tugas dan tanggung jawab pelayanan kesehatan secara timbal balik, baik vertikal maupun horizontal (PERMENKES 001 tahun 2012).

Sisrute mempunyai fungsi dalam membantu perumusan kebijakan strategis dan teknis dibidang kesehatan rujukan yang berkesinambungan dan mendukung penyelenggaraan pemerintahan daerah di bidang kesehatan. Pemerintah telah mengeluarkan Surat Dirjen Pelayanan Kesehatan pada tanggal 10 Desember 2018 tentang Permohonan Penggunaan Sistem Rujukan Terintegrasi kepada seluruh Dinkes kab/kota/provinsi.

Pemberian akses aplikasi ini ditujukan kepada seluruh Rumah Sakit rujukan. Rumah Sakit dapat melakukan rujukan ke RS yang lebih tinggi sesuai dengan kebutuhan medis pasien yang dirujuk. RSUD Dr. R.M. Djoelham Binjai telah menerapkan aplikasi Sisrute pada bulan Februari tahun 2019. Setelah diterapkannya aplikasi ini dirumah sakit, tercapai cita-cita pelayanan Rumah Sakit yang mampu laksana, tepat guna, dan efesien dalam pelaksanaannya. Ada alasan mengapa aplikasi Sisrute ini dibuat, yakni ruang perawatan penuh, penolakan pasien, lambatnya pelayanan awal di IGD, proses rujukan yang lama dan sebaran distribusi tenaga kesehatan yang tidak merata. Karena alasan itulah, dibuatnya aplikasi ini sebagai sebuah solusi percepatan layanan digital.

Penelitian sebelumnya yang berkaitan dengan sistem rujukan rumah sakit menyatakan sangat membantu pihak manajemen rumah sakit dalam pembuatan sistem rujukan (Gultom \& Sopian, 2018).

\section{METODE PENELITIAN}

\section{A. Jenis Penelitian}

Jenis Jenis penelitian adalah penelitian deskriptif. Penelitian dilakukan pada bulan Desember 2019-Januari 2020. Penelitan dilakukan di RSUD Dr. R.M djoelham. Sumber data yang digunakan adalah Data sekunder yang sudah ada di rumah sakit.

B. Analisis Data

Dalam penelitian ini analisa data dilakukan secara deskriptif melalui observasi, penyajian dan penarikan kesimpulan, sehingga diperoleh gambaran tentang Sisrute.

\section{HASIL DAN PEMBAHASAN}

\subsection{Hasil}


SISRUTE (Sistem Rujukan Terintegrasi) berbasis IT ditujukan untuk meningkatkan kinerja fasilitas pelayanan kesehatan dan memaksimalkan proses rujukan sesuai kebutuhan medis pasien dana kompetensi fasilitas pelayanan kesehatan. Penggunaan SISRUTE di RSUD Dr. RM Djoelham Binjai dengan membuka website Sisrute.rujukan.web.id. Kemudian petugas SISRUTE mengisi username dan password, kemudian masuk ke tampilan menu utama/Home, dalam menu utama pilih rujukan keluar, setelah tampilan menu rujukan keluar maka petugas memasukkan identitas pasien yang ingin dirujuk. Kemudian mengisi idnentitas pasien, rujukan pasien, dan melampirkan hasil lab (jika ada).

\subsection{Pembahasan}

\section{A. Alur Sisrutedi RSUD Dr. RM Djoelham Binjai}

Dalam menjalankan Sisrute, dibutuhkan alur sebagai berikut:

1. Tenaga Kesehatan mencari informasi dan saling berkomunikasi melalui aplikasi SISRUTE (dengan cara Chat /Video Call) sesuai dengan kebutuhan pasien.

2. RS perujuk memberikan data informasi tentang kondisi pasien kepada RS yang menerima pasien rujukan tersebut. Informasi kondisi dari pasien tersebut dilampirkan di halaman rujukan (berbentuk data).

3. RS penerima pasien rujukan mengkonfirmasi data-data pasien secara lengkap agar rujukan dapat segera di proses.

4. Pasien rujukan datang ke RS penerima rujukan menggunakan Ambulance dan pasien membawa berkas rujukan.

5. RS penerima rujukan akan melayani pasien rujukan jika data pasien sudah lengkap. Lalu rujukan akan segera diproses oleh pihak Rumah Sakit.

\section{B. Kendala Aplikasi Sisrute di RSUD Dr. RM Djoelham Binjai}

Sebagai aplikasi baru, Sisrute memiliki kendala dalam pelaksaaan yaitu:

1. Data-data pasien yang dirujuk tidak lengkap sesuai dengan form yang ada disistem sehingga menyulitkan RS penerima menerima jawaban.

2. Server internet fungsi utama yang tidak stabil sehingga operator memiliki kendala dalam waktu memaksimalkan kinerja Sisrute.

3. RSUD Dr. RM Djoelham Binjai belum memiliki SOP tertulis untuk pemakaian aplikasi Sisrute.

4. Masih ada operator di Rumah Sakit yang kurang menguasai penggunaan Aplikasi Sisrute tersebut.

\section{Kelebihan Aplikasi SISRUTE di RSUD Dr RM Djoelham Binjai}

Adapun aplikasi Sisrute memiliki kelebihan sebagai berikut:

1. Aplikasi Sisrute menampilkan seluruh daftar tujuan yang lengkap dengan alatalat kesehatan medis yang bisa disesuaikan dengan kebutuhan pasien.

2. Perujuk bisa dapat kepastian terhadap pasien yang akan dirujuk.

3. Waktu respon dari RS yang dirujuk tidak terbatas/tidak memiliki waktu kadaluwarsa sehingga apabila RS yang dituju lama memberi balasan maka waktu rujukan masih aktif/tidak dinonaktifkan.

\section{KESIMPULAN}

1. Aplikasi SISRUTE sangat membantu percepatan pelayanan, memudahkan informasi rujukan terkait kejelasan pasien dapat diterima oleh RS yang dirujuk, mudah melakukan konsultasi dalam penanganan pasien lebih terarah dan meminimalkan penolakan pasien dengan koordinasi dan komunikasi antara RSUD Dr. RM Djoelham Binjai dengan RS yang ingin dirujuk/RS penerima. 
2. Kendala menggunakan aplikasi SISRUTE di RSUD Dr.RM Djoelham Binjai yaitu: (a) Server Internet di RSUD Dr. RM Djoelham Binjai tidak stabil, (b) Masih ada RS perujuk yang tidak komitmen dengan informasi di sistem ini, (c) Data-data pasien yang dirujuk tidak lengkap sesuai dengan form yang ada di sistem sehingga menyulitkan RS penerima menerima jawaban.

3. Kelebihan menggunakan aplikasi SISRUTE di RSUD Dr.RM Djoelham Binjai yaitu (a) Perujuk bisa mengetahui tujuan Rumah Sakit sesuai kebutuhan pasien, (b) Memastikan pasien sudah mendapatkan perawatan dari RS yang dirujuk, (c) Perujuk bisa dapat kepastian terhadap pasien yang akan dirujuk.

\section{REFERENCES}

Dr. Dr. Khalid Saleh, SpPD-KKV, 2016 Manual Sistem Rujukan Terintegrasi (SISRUTE), Makassar.

Gultom, S. P., \& Sopian. (2018). Analisis Kebutuhan Tenaga Rekam Medis Berdasarkan Beban Kerja Di Bagian Pelaporan Rumah Sakit Khusus Ginjal Rasyida Tahun 2018. $3(2), 485-493$.

Ignasius, Luti. 2012. Jurnal Kebijakan Kesehatan Indonesia. Yogyakarta: Universitas Gadjah Mada.

Kemenkes RI. 2018. KEMENKES RI No. HK.02.02/III/4776 Tentang Review Kelas Rumah Sakit. Jakarta: Indonesia.

Permenkes RI. 2012. PERMENKES 001 Tentang Sistem Rujukan Terintegrasi. Jakarta: Indonesia.

Permenkes RI. 2018. PERMENKES RI No. YR.04.02/III6014 Tentang Penggunaan Sisrute. Jakarta: Indonesia.

Undang-undang Nomor 44 Tahun 2009, Tentang Rumah sakit. Jakarta: Kementrian kesehatan.

\section{BIOGRAPHIES OF AUTHORS}

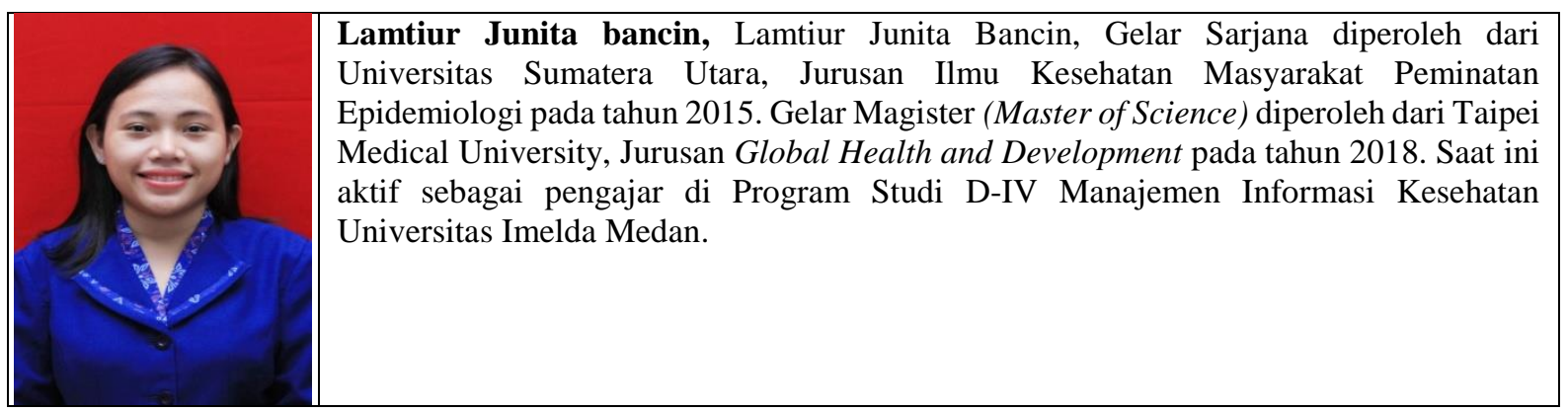

